\title{
The Virtual Reality of I mprisonment: The I mpact of Social Media on Prisoner Agency and Prison Structure in Russian Prisons
}

Piacentini, L., and Katz, E., 2018. The Virtual Reality of I mprisonment: The I mpact of Social Media on Prisoner Agency and Prison Structure in Russian prisons. Oñati Socio-legal Series [online], 8 (2), 183-204. Received: 20-04-2017; Accepted: 23-01-2018. Available from: https://doi.org/10.35295/osls.iisl/0000-0000-0000-0933

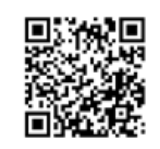

\begin{abstract}
Prison agencies around the world are reporting a rise in the use of illicit communication devices in prison. Nevertheless, there have been no criminological studies examining prisoners' online behavior. Using Russia as a case study, this paper reports findings from new research on prisoners' illicit internet use and the effects on prisoner agency and prison structure. Our main finding is that Russian penality sits at the nexus of two processes. First, penality is de-institutionalised whereby the prison, discursively speaking, is no longer fixed to a built form. Second, penality is reflexively re-territorialised by placing prisoner agency onto a third space. The paper presents a new conceptual framework of prisoners as absent, which reveals Russian penality as culturally contingent and politically resilient. The interplay between deinstitutionalisation and re-territorialisation has produced a new penal imaginary - a carceral motif for the twenty first century - in the form of a virtual world.
\end{abstract}

\section{Key words}

Russia; prisoners; agency; social media; structure; absentism

\section{Resumen}

Con Rusia como estudio de caso, este artículo informa acerca de los hallazgos de nuevas investigaciones sobre el uso ilícito de Internet por parte de los reclusos, y de los efectos sobre la agencia de los reclusos y sobre la estructura de la prisión. Nuestro principal hallazgo es que las prisiones de Rusia son el punto de encuentro de dos procesos: primero, la vida en prisión se desinstitucionaliza, de modo que la prisión, en sentido discursivo, ya no está vinculada a una edificación; segundo, la existencia carcelaria se reterritorializa de forma reflexiva, a través de la traslación de la agencia

\footnotetext{
* Laura Piacentini, PhD, FRSE, is Professor of Criminology at the School of Social Work and Social Policy at the University of Strathclyde Glasgow. She is also Associate Director of the Scottish Centre for Crime and Justice Research. For over twenty years, she has conducted research into cultures of punishment on postSoviet prisons and has published widely on this subject. This research for this paper is drawn from her Leverhulme Fellowship 2015-2017. Postal address: The School of Social Work and Social Policy, University of Strathclyde, Glasgow, Scotland, UK. Email address: laura.piacentini@strath.ac.uk.

"Elena Katz, PhD, is Senior Research Associate at the School of Geography and the Environment, The University of Oxford; S Parks Rd, Oxford OX1 3QY, UK. She is a Humanities and Area Studies Scholar. She has worked on two studies of Russian prisons.
} 
del prisionero a un tercer espacio. El artículo presenta un marco conceptual nuevo de prisioneros en ausencia, que revela que la vida carcelaria de Rusia es culturalmente contingente y políticamente resiliente. La interrelación entre desinstitucionalización y reterritorialización ha producido un nuevo imaginario - un motivo carcelario para el siglo XXI - en forma de mundo virtual.

\section{Palabras clave}

Rusia; reclusos; agencia; redes sociales; estructura; ausencia 


\section{Table of contents / Índice}

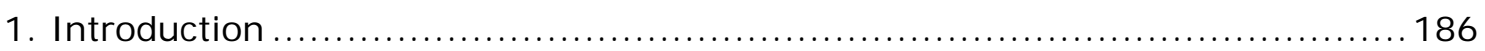

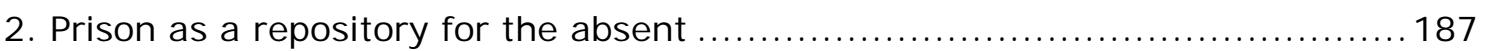

3. Cultural determinants of agency and structure in Russian prisons ............... 189

4. The visible bureaucracy of rights mobilisation ................................. 190

5. Methods in researching user-generated content on prisons ..................... 192

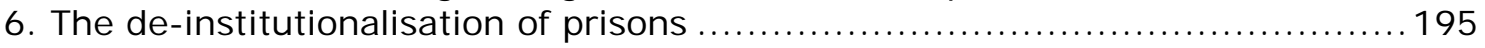

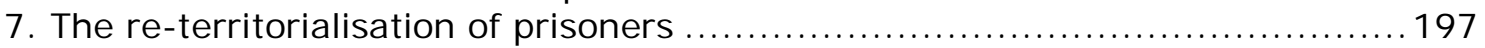

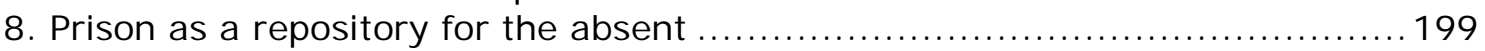

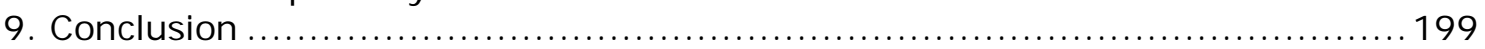

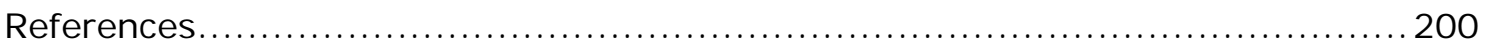




\section{I ntroduction}

The ubiquity of social media and its extraordinary capacity to create connections between people in a visible way is the backdrop to this paper, which explores Russian penal actors' social media engagement and the effects of this on agency and structure. There has been an unprecedented rise in internet use in Russian prisons by prisoners and prisoners' families that has produced a dynamic online world of prisoner blogs and Facebook-style pages. The data presented in this paper draws from a new study that examines the behaviours of Russian prisoners and their families who use the internet to engage with incarcerative processes. ${ }^{1}$ We define prisoner agency as an individual's capacity to determine their prison experiences in ways that can shape their individual behaviour in a highly restrictive structural context. While there is no universal definition of agency, it is mostly associated with resistance, social change and "celebrating the dignity, will and potency of prisoners' political actions" (Pittendrigh 2015, 157; see also Bosworth 1999). Yet, there are parts of agency that are overlooked, including how it incorporates structural and cultural determinants such that it has come to be defined unsatisfactorily despite it becoming the "placeholder for something we want to describe" (Pittendrigh 2015, 158). Consequently, agency and structure are topics researched in binary form with agentic behaviour encompassing acts that resist, or stand in opposition to, prevailing structural arrangements (Pittendrigh 2015). Rubin (2016) argues that structure, defined as "those forces or patterns external to prisoners that structure or shape their behaviour" (Rubin 2016, 1) has become a minor lens for understanding agency. Structure not only contributes to prisoner behaviour, but also is perhaps even coproductive of agency. Examining agency and structure as not in opposition allows for a more critical vantage point from which to understand prisoner behaviour, and is especially instructive for advancing a more nuanced cultural understanding of Russia's penal development.

Social media is a compelling starting point for a paper on Russian prisons because of the ways it generates visibility but also temporal and spatial connections. Across different communities, the cooperative, collective and, at times, non-deliberative communication that takes place in social media has ignited discussions on the production and reproduction of "intimate publics", "media life" and "electronic intimacy" (see Deuze 2011, Hjorth and Lim 2012, 478, Rosen 2012, for debates). Gibson $(2016,632)$ argues that "social media does not simply report on ritual in an outside, unmediatized space; it is itself performative of social ritual", while others comment that social media generates social practice and is a visible reflection of the aspirations and desires of those producing online content. Moreover, social media increases the visibility of all forms of expression that in the absence of real-life cues creates an "online disinhibition effect" (see Suler 2004 and Fletcher 2006, Pauwels 2011).

Following this point, our key question is: What are the effects of the visibility of Russian prisoners on social media? Disentangling prisoners and prisons from social media, using the data available to us, has not been an easy task. However, some informed assessments can be made. Our main finding is that Russian penality sits at the nexus of two processes: the de-institutionalisation of prisons followed by reterritorialising of prisoners. De-institutionalisation refers to a new spatial geography no longer fixed to a specific institutional site or built form. Re-territorialisation is the process that places prisoner agency onto a visible thirdspace, which has been described as the safe ground that you go to voluntarily mainly because it is a good place to be, is intended to be enjoyable and normal, and establishes a sense of place (Soja 1998). More recently, online space has been discussed as stretching and embedding social relations across large and even infinite distances (Crawford and Hutchinson 2016) and this "[has] problematized the territorial dimensions of space

\footnotetext{
${ }^{1}$. The project is funded by the Leverhulme Trust, UK, and is titled: Towards a Sociology of Rights Consciousness Amongst Russian Prisoners.
} 
and individual experience of spatiality, as much social interaction is conducted through non-territorial spheres such as "cyber space'" (Crawford and Hutchinson $2016,1196)$. We add a cautionary note about the extent to which we can claim that social media has made Russian prisons public given that social media can be selective in what appears on it. Our interest instead lies in the tensions between social media use and its apparent ubiquity across penal culture, which suggests to us a complex interaction between prisoners constructing their prison experiences online, and the resilience of Russia's socio-carceral reality. How prisoners live in collective communities and cope in high prison population sites constitutes this resilience (Piacentini and Slade 2015).

The instantaneous online visibility of Russian prisoners contributes to punishment and society scholarship in two key ways. First, in improving our understanding of the ways in which prisoners become visible actors outside of conventional person-toperson contact. Punishment and society scholarship has yet to fully interrogate this question yet it is significant for understanding how - and, importantly, where prisoner agency occurs and how the everyday self is expressed, mediated and authenticated. ${ }^{2}$ Second, in engaging comparatively and globally in debates about the role of the prison and the construction of state power. There is a growing scholarly literature on the rise of the penal state in other parts of the world that is often framed in terms of flows from the global North to the global South (Carrington et al. 2012). "The North/South divide", write Carrington et al. (2012, 2), "refers to the divide between the metropolitan states of Western Europe and North America on the one hand, and the countries of Latin America, Africa, Asia and Oceania, on the other", it is a "metaphor for power relations" between a centre and a periphery. Notably, the former Soviet Union is conspicuously absent here yet Russia's penal story is changing and has made a very public and cultural volte face from a vast penal degradation system that hid many millions of prisoners into one where prisoners have global collective visibility. The effect, therefore, is some cultural collisions with Russia's exceptional penal past.

\section{Prison as a repository for the absent}

A significant theoretical contribution we make to punishment and society scholarship is in situating our findings within a conceptual framework of "prisoners as absent", which draws from the theoretical work of the political geographer Jenny Edkins (2011) and the sociological theorisations of haunting and absence by Avery Gordon (2011; see also Rhodes 2004). A conceptual framing of prisoners as absent is underdeveloped in world prison sociology. It is a useful analytical framework nevertheless because it reveals how the spatial and temporal qualities of prisoner visibility both add to and contest the processes through which prisoners develop agency. While all imprisonment presupposes a world cut off and hidden, punishment and society scholarship has yet to conceptualise carceral sites as repositories for the absent. This is an intriguing omission given the unprecedented growth in world penal systems and the enormous societal impact prison has as a system designed to exclude and hide. For the purposes of this paper, and for the first time we believe in world prison sociology, ${ }^{3}$ we consider conceptualising prisoners as absent. We have begun to look closely at the research conducted in human geography on missing people and particularly the ways that contemporary political systems treat persons instrumentally as objects to be administered. In her book Missing: Persons and Politics, Jenny Edkins (2011) trains attention on mass atrocities that cause vast

\footnotetext{
2 Desk-based or sociological scholarship can sometimes struggle to capture this, particularly when it considered that prison access is often denied, policy documents redacted and one-to-one interviews with prisoners can be strained by the presence or awareness of prison personnel (see Drake et al. 2015, Calavitta and Jenness 2015).

${ }^{3}$ Human geography has very recently started to look at prisoners and absentism in the UK context (see Moran and Disney 2017). Our work on this is different insofar as we do not explore the methodological possibilities of analysing geography as absence and instead locate prisoners as absent within sociology.
} 
numbers of people to go absent not only as a consequence of political chaos, but also because of design and strategy. Edkins argues that governments today are concerned with populations and not people and that prevalent forms of political or biopolitical governance both objectify and instrumentalize the person to the point that: "[c] ontemporary politics does not see the person as such, only the person as object" (Edkins 2011, viii). Thus, bureaucratic processes lead to persons becoming deindividuated. Tension then arises between "political features of a person who has gone missing" and a "politics that misses the person" (Edkins 2011, 10). Gordon (2011) considers the language of "haunting" to describe abusive systems of power and how they make themselves known in everyday life through modern forms of dispossession, particularly in contexts such as slavery and imprisonment. Referencing people and places "hidden from view" (Gordon 2011, 3) Gordon emphasises that "haunting" is not about invisibility or unknowability but about showing what is "there in the blind field" (Gordon 2011, 3). A sense of haunting emerges from the trauma of being absented into imprisonment because of the degradations and organised forces of power that create social death (see also Rhodes 2004).

Excluded from Edkins's analysis of the political objectification of absent people, but more present in the work of Gordon and Rhodes, are prisoners despite many themes resonating, particularly the ways that in which carceral authority prioritizes bureaucracy. For example, in Mary Bosworth's work in immigration detention centers (IDC), she considers how the visible bureaucracies of administrative justice have rendered asylum claimants erased and estranged (see Bosworth 2016). The only language of currency and meaning in IDCs is administrative and bureaucratic, with little or no discursive convergence between the hidden recipients of bureaucracy and a quasi-penal structure. In short, the adversarial context places bureaucracy at a premium and enhances the absent-ism of prisoners. Further resonance between prison sociology and geographies of the missing scholarship is in the cultural value that is ascribed to people who go absent, for according to Edkins, "a politics of the missing could be deemed incomplete without some consideration of the invisible person, the person who doesn't even begin to count" (Edkins 2011, 7). This is an instructive insight when considered in penal contexts. First, most of those held captive return through what criminologists call a life sentence served by instalments. Prisons, therefore, represent journeying; of leaving and constant return. This can be a rather messy practice; more than a situation of absence, imprisonment in Western prisons is also a multiple experience of absence. This certainly suggests a temporal quality of the kind that Edkins outlines but, moreover, it has a political quality: a missing person is someone of "no importance". Second, prisoners experience an ambiguous absence. On the one hand, the prison itself has a visible and static presence in the everyday and yet, on the other hand, the prisoner her/himself goes absent, has disappeared and reached a threshold of missingness. Missingness requires absence, but an absent prisoner may not experience their own missingness as absence because whereabouts can be established (she or he is in prison) and the absent person is at a place expected or required. Yet, the metaphor of absence advances world prison sociological scholarship because it defines how a person's absence interferes with a person's sense of self, both in confinement and on release, and is as much a stage of being, as a situation (see Payne 1995 and Parr and Fyfe 2013). Consequently, in the state of being a prisoner, a person must navigate multiple identities and representations of the self that includes othering through absence. Ultimately, if the prison is a repository for the absent, how a prisoner copes with the prison's complex terrain can either heighten or maximise their sense of absence depending on the spatial and temporal conditions of being confined and hidden. For scholars of the prison, the key challenge then is how to understand the ways that prisoners occupy a paradoxical positon; they have an absent presence. A conceptual framing of prisoners as absent can, therefore, assist in shaping our understanding of the non-binaried ways that agency (re-territorialisation) and structure (de-institutionalisation) cohere and connect in Russian prisons. 
We structure the paper as follows: the following section discusses the cultural determinants of agency and structure in Russian prisons that provide the context for understanding agency and structure as non-binaried; we then discuss our methodology before presenting our findings and analysis; and, in our conclusion, we examine the risk of repercussions from prison authorities for violating prison rules on internet access.

\section{Cultural determinants of agency and structure in Russian prisons}

Since Tsarist times, penality in Russia has mirrored sweeping cultural, economic, political and spatial ambitions creating an acutely politicised penal form - a penal aberration hiding millions of so-called criminals - the legacies of which are still being felt today. The Soviet penal system, particularly Stalin's Gulag (1934-1953), was exceptional in scale and brutality. Absenting prisoners was enabled by a culture whereby state and person were locked into a political project that required a quite different process (compared to western penality) of excluding prisoners: penal punishment on an enormous scale, clandestine trials, subverted legality and targeted mass and individual kidnappings (see Barnes 2011). Draconian penal policies, victimisation and every day violence continued well into the late 1950s. It was following the publication of Aleksander Solzhenitsyn's Gulag Archipelago in 1973 that the acronym Gulag (Glavnoe upravlenie ispravitel'no-trudovykh lagerei i kolonii, or the Main Administration of Corrective-Labour Camps and Colonies of the GPU/NKVD, and later MVD) began to resonate across the world and came to symbolise state repression. The thousands of Gulag memoirs, archival documents and state and private collections ${ }^{4}$ paint a vivid and complex picture of a hidden system and a boundary-less politicised penal structure that mirrored Soviet society. According to Khlevniuk, "Gulag, just like the non-Gulag, was neither socially nor economically homogenous (...) and that it is no exaggeration to say that the more 'benign' spheres of the Gulag converged with the cruder spheres of the non-Gulag" (Khlevniuk 2015, 484). This systematic use of imprisonment was taken to the extreme with state violence, exile and mass deportations intended to not simply eliminate enemies of the state, but also realise and preserve an idealized image of the "politicosocial body, of the People-as-One" (Holquist 2003, 32).

This is interesting in revealing certain things about agency and structure outside and inside prisons in the former USSR. First, is that if agency was the collective pursuit of a Soviet utopia, were citizens self-aware about what it was to belong to this collective ideal over and above the parts of Soviet idealisation that could be resisted? Secondly, when considering imprisonment, a question arises about whether agency can be understood as other than resistance precisely because of the symbolic relationships between person and state that came to be embedded in social and political institutions. If all persons were, to paraphrase Marx, the personifications of economic categories and brought into the ideology of the state, then, in the penal sphere, the role of structure is both a communication of, and constraint on, prisoner agency because of limits set to individual action; prisons may produce perfect proletarians, but they also punish anti-Soviet criminality (Callinicos 2009). Thus, in order to make sense of the sociology of punishment ${ }^{5}$ in Soviet Russia, it is helpful to consider prison agency and structure as indivisible, and operating within the framework of existing cultural and social relations. Prisons, therefore, are distinctive spaces of experience constituted by custom and tradition (prisons are contained, contextualised and rendered concrete).

\footnotetext{
4 The literature on Stalin's Gulag is voluminous but we draw the reader to some well-known texts: Grossman, (1965/2009), Ginzburg (1967), Solzhenitysn (1973) and Ratushinskaya (1988).

5 Our italics are intended to underscore the need to reconceptualise the Gulag and the role of prisons in Soviet society more generally. A special issue of the Soviet and Eurasian Studies journal Kritika in 2015 devoted to Renaissance of the Scholarship goes a remarkable way to achieve this (Baberowski et al. 2015, 470).
} 
The prisoner resistance movement amplifies the spatial and temporal experience of incarceration in Soviet Russia by taking the body out of the physical boundaries of incarceration to create a politics of penal absence and new visual, literary and popular culture imaginaries of incarceration. This suggests incarceration as an embodied performance constituted collectively of people who are and who are not present in society. Memoirs have the capacity to remind the reader not only of the kinds of cognitive maps and personal experiences required to survive a brutal penal experience, but also the interplay and ambiguities between agency and structure during a long period of totalitarianism where state and person are "one and the same". In our view, the Gulag memoir is distinctive and different from the current context of online prisoner web-sites insofar as the memoir is a historicized and politicised form (Paperno 2009) written mainly by a Russian intelligentsia for a Russian intellectual audience first and foremost (I bid. $)^{6}$ The written memoir is subject to the vagaries of publishing with many now out of print. Similarly, letter writing in prisons is different from online prisoner content as it is constrained by the bureaucracies of prison management, prison censorship and penal control. While the written memoir was personally and socially transformative in generating international reaction with the brutality of Soviet prisons, the internet provides for immediate identification with like others, in the absence of offline contact, with the potential for vast - seemingly limitless - anonymous interaction. Moreover, in unmaking one's invisibility so pervasively online, prisoners narrate real life realities for - crucially real life audiences. The data is rich, numerous, naturally occurring and allows for continual reporting. Being online can help geographically dispersed groups connect and support prisoners when the support is not there offline. However, our reading of prisoners' online chat and unfolding agency speaks less directly of the political experience of punishment, which is what the Soviet memoir sought to achieve, and more about the resilience of prisons. That is not to say, however, that today's culture of punishment in Russia is not politicised, or censored, but rather that prisoner agency coheres around a need for self-expression.

In summary, in twentieth century Russia, prisoner agency was a complex blend of resistance and engagement. Agency and structure operated together in quite nuanced and culturally specific ways to generate a Soviet penal body: an absent person but one also visible because she/he was a cog in the state machine. In this sense, prisoners occupy a paradoxical historical position in Russia; they have an absent presence. In the section that follows, we outline how the collapse of the USSR paved the way for new forms of prisoner visibility through human rights.

\section{The visible bureaucracy of rights mobilisation}

Russia's geo-political position to Europe, alongside the exposure of systemic penal brutality after the collapse of the USSR created a penal reform context that sought to bring Russia into alignment with the institutions of Europe (Bowring 2013). Prisons are a problem in Russia because of the way the Soviet Union organised its institutions, the subversion of criminal law, and because the regime organised the penal system for its own benefit. A raft of new civil society measures aimed at building a better society were created and embedded in legal and institutional infrastructure (norms, policies and practices). That rights is now a common term in contemporary Russian penal discourse can be evidenced from the slightly frenzied importation of international norms, changes to the procedural, civil and criminal codes from 1991 and in the bold public assertions from the Russian prison service that Russian prisons are now "rights-facing" (Piacentini and Katz 2017). ${ }^{7}$ There is no question that for twenty-five years there has been penal alignment between Russia

\footnotetext{
${ }^{6}$ Paperno (2009) notes that stories from the barely literature and working class did appear but these would normally be edited by intellectuals.

See also Federal Penitentiary Service of Russia 2013. After the collapse of the USSR much discussion took place over civil and criminal procedure and how to "replace the word Soviet with European" in the criminal and penal codes (see Piacentini 2004).
} 
and the European Union; but the important point is that penal reform has undoubtedly brought prisons out of a dark and troubling Soviet shadow and made prisoners, and their carceral experiences, hyper visible. While the success of mainstreaming rights discourse in penal policy, standards and practices has been arguably very poor, it is also significant that human rights created a new sociocarceral reality with prisoner safety, well-being and rights framing the new penal context.

Comparatively, prisoners almost everywhere have the right to access complaints procedures. Hannah-Moffat (2014) argues that accessing procedures may instill a sense of agency particularly in rights litigation, while others develop agency from direct forms of prisoner protest (see Hannah-Moffat 2001, 2014). Despite the awareness of conditions across the world, there remains a paucity of scholarship on prisoners' subjective experiences of both punishment and rights, which is concerning since human rights abuses are becoming more common and world prison populations remain high (see Coyle 2009). Russia has not evaded these trends with organisations supporting prisoners having their activities at best curtailed and at worst destroyed, offices ran-sacked and closed, surveillance and reports of threats of violence and even death (see McAuley 2016). The situation has worsened under President Vladimir Putin, whose Soviet-style authoritarianism has led to a hardening of criminal law for minor offences and a weakening of civil society (Bowring 2013), thus imposing significant constraints on ensuring effective state/penal accountability. With public discourse stifled by a weakening civil society infrastructure, it is notable that criminal justice reform has been patchy. International and European legislative improvements to standards have been woefully implemented with many prisoners being failed by poor domestic commitments to human rights (van Riel 2015).

While the material and legal situation for prisoners is worsening, criminological research in Russian prisons is almost non-existent and this aggravates the hiddenness of Russian carcerality. So much so that prisoners are absent again in that access to prisoners by academics, lawyers and third sector groups is diminishing. Thus, it would appear that a historical tension has re-surfaced between two different spatialities: visibility (through legal entitlements) and absent-ism (due to a weakening of rights more broadly). Crucially, post-Soviet prisons are carrying forward Russian national identity and cultural tropes around the individual versus the collective (Piacentini and Slade 2015). It is these historical dynamics of incarceration, plus the failure of the Russian government to meet international obligations, that have reduced access to rights through the normal bureaucratic means and to perceive them as anything other than a paper exercise (see Bowring 2013).

As civil society weakens in Russia, there has also been exponential rise in social media. Social media has come to Russia later than many other world nations, yet it has, nevertheless, raised awareness of the political climate (Pomerantsev 2014). There have also been accusations that social media sites are used by the security services to troll and provide surveillance on protest figures. The effects have been troubling with high profile murders linked to the opposition of the Putin regime, the shutting down of independent news stations and newspapers and draconian legislation introduced in criminal justice. One unanticipated outcome of the social media boom are prisoner websites enabled by the circulation of illicit cell phone devices in Russian prisons. Cell phones are among the most popular contraband to smuggle into Russian jails (The Moscow Times 2015). It is impossible to say how many mobile phones are in use across Russian penal colonies and prisons but their circulation has been described by Pallot (2013) as "extraordinary", with differences among colonies in the opportunities prisoners have for accessing electronic devices and keeping them concealed from personnel. It would appear that drones are the most popular methods for depositing phones into penal colonies. Pallot (2013) comments that prisoners are often: 
chatting on the phone for hours on end with their 'loved ones' behind bars and the way that prisoners have easy access to Internet dating sites, where they can make contact with zaochnitsy women who want to have a relationship with a prisoner. Of course, there are differences among colonies in the opportunities prisoners have for accessing electronic devices and keeping them concealed from personnel, but still it is not an exaggeration to say that their importance must far outweigh any impact the official communication media can have at the present time-but in what way, it is impossible to say. The widespread existence of illicit communication devices also draws attention to the way new technologies may become a vehicle for challenging penal authority. (Pallot 2013)

The use of communication devices raises the inevitable question of whether prisoners communicating online can challenge the official authority of the prison. ${ }^{8}$ Prisoner internet use is certainly transformative in that there are very few jurisdictions around the world where prisoners are communicating online during custody. It is too early to say whether prison litigation is taking place because of online blogging or forum engagement but we note that while engaging online does not make prisoners entirely free, or safe, it does transport them to a reality that makes them feel not entirely absent from the outside world.

At the everyday level, enabling wide spread mobile phone use is Russia's unique penal architectural form. Russia's penal architecture has been conceptualised as "carceral collectivism"; a polyopticon (the many viewing the many), which is an inverse of the panopticon (the few watching the many). Carceral collectivism is grounded by three elements: a system of penal governance based on mutual peer surveillance, dispersing authority and governance to prisoners themselves, and communal living made possible by the spatial and temporal structuring of prison life through the housing of prisoners en masse in dormitories (Piacentini and Slade 2015, 181). Large detachment blocks holding up to two hundred prisoners present challenges for the authorities in searching for contraband and illicit devices and can, in part, explain the ease with which a mobile phone can be smuggled and circulated. Jamming or blocking signals and networks, stop and search, using dogs to sniff out the ionization of cell-phone batteries, surveillance and using drones are the main detection methods. However, not every inch of a penal colony or prison can be blocked from a mobile signal, so these efforts to stop accessing the internet are viewed by some as futile. Mobile phones may be a valuable resource for drug smuggling, but they are not necessarily used for criminal purposes and are an invaluable communications device for staying better connected with home. Getting involved with online chats about jail life can be a huge help to prisoners. Despite this practice, the Russian government introduced in 2016 new laws banning mobile phones use by prisoners and their families, who could be jailed for accessing the internet on prisoners' behalf even if they are not contacting prisoners directly.

In summary, Russian prison are entering a new era of online visibility that has arisen somewhat inevitably from the social media boom in Russia. When prisoners communicate, do they perceive of themselves as developing agency through resistance in the historical tradition of Solzhenitsyn? Alternatively, are they accessing the internet merely to be like those on the outside or to normalise their everyday lives? This development whether intended or not has left punishment porous and leaky - in quite profound and unprecedented ways for a former totalitarian country - and this may affect how the prison is studied and challenged as an object, a subject and a level of analysis.

\section{Methods in researching user-generated content on prisons}

There are over thirty prisoner websites in Russia, designed by prisoners, families, third sector groups and former prisoners. The web-sites offer advice on everything

8 There is evidence of some online activism, but this is directed mainly by the families of high profile prisoners, such as the Oligarch Aleksei Kozlov. 
from legal entitlements, travel advice, access to girlfriends and wives, entertainment and cultural and literary historical resources. Amongst the websites accessed for our main research study were: ${ }^{9}$

1. http://bidla.net/ (For macho/real men)

2. http://gulagu.net/ (Independent human rights activists and prisoners' relatives fighting for humanisation of punishment in Russia)

3. https://nevolia.ru/ (Prisoner-related topics discussion platform)

4. http://vk.com/public51217036 (For prisoners' families)

5. http://zeki.su/ (Soyuz zaklyuchennykh, prisoners' union)

6. http://www.vturme.ru/ http://www.tyurma.net/ (Legal and practical support)

7. http://vkapkane.net/ (For prisoners' wives)

8. http://prisonlife.ru/ (A basic but well known prison portal)

9. http://www.syzo.ru (This web advertises itself as a web for zeks and prisoners)

10. http://fsin-russia.ru/ (Forum of informal communication between the FSIN personnel)

11. http://www.zekovnet.ru (Charitable foundation: Imprisoned Rus)

Our methodological approach involved using an online ethnography - netnography that combines conventional ethnographic approaches with engaging in virtual reality environments (Hines 2015). Following full university ethical approval, we first established criteria for inclusion in our study based on whether respondents are currently serving a period of custody. We then selected one web site from the list above because it is for prisoners, supported by prisoners and managed by a moderator. ${ }^{10}$ In order to protect the web-site's identity, we refer to it using a pseudonym: www.jailRussia.org. For the purposes of this paper, the data we refer to is secondary public data (SPD), which is data gathered by someone else (institutions, NGOs, or in this case internet sites) and for some other purpose other than the one currently being considered (in this case, web-chat rooms set up for semi-public use for prisoners and others) (Boyd and Crawford 2012). We chose SPD analysis as we did not participate in interviewing the prisoners. ${ }^{11}$ The web-site's own terms and conditions for users are clear and within these terms and conditions there are contained clauses on how one's data may be accessed by third parties. The web-site is well established as an "open public platform" that aims "to reach as many prisoners and people as possible". The next step was to seek agreement with the web-site's moderator. The moderator accepted our post of an introductory message that established informed consent through outlining that: we were academics from UK universities; we were accessing data for research purposes (including dissemination); that we would treat all data collection as confidential, and that we would not refer to the handles by name but would instead create pseudonyms. We received no objections to utilising the secondary data for our research project. Other third sector groups, families and advocate groups also use the web-site and so the secondary data has been published beyond the site's borders. It is important to note that data analysis cannot be justified solely on the grounds that it is accessible. The expectations around public and private awareness of the web-site are met by users having to apply to join, click agreement with terms and conditions and web-site

\footnotetext{
${ }^{9}$ For full details on prison related internet web-sites in Russia, see Piacentini and Katz 2017.

10 In the interests of the safety of the prisoners and the prisoner forums, we do not disclose which web site.

${ }^{11}$ We have set up a blogging handle to interview prisoners that has passed full university ethical approval and meets the standards of the British Sociological Association and the British Society of Criminology for conducting social science research online. Both societies, in their ethics protocols, acknowledge that social media data brings new contextual challenges, which the more traditional approaches are not equipped to deal with. We are establishing a new strategy and procedures for primary data collection for future data analysis following some challenges in participant recruitment.
} 
moderation. We observed anonymization throughout, which was crucial given the subject matter and demographic. This minimised the risk of harm to any prisoners whose data we used. One issue is the reasonable expectations of prisoners that people seeing their data are like-minded (prisoners or persons sympathetic to prisoners). We decided that, while users may expect others viewing their profile to be like-minded, they may also expect strangers to view their profile, so the data is not private. When writing up our results, we have not published full data sets and have paraphrased from Russian into English.

There are limitations to the data: whether the data is accurate, the question of "real identity" (Hines 2015) and, importantly, whether we were in fact reading blogs from prisoners, or from others who were presenting themselves as prisoners. The limited scholarship on online social science research acknowledges that the internet gives promise of multi-faceted identities (Kozinets 2015). Our view was that this is not necessarily problematic since the alteration of identity is a natural consequence of social life and is not simply an idiosyncrasy of online life. Indeed, whether or not the real identity is that of a prisoner or not is not the matter under study. We were very mindful of the point made by Kozinets (2015) that every online interaction is a social action and a communicative performance that requires contextualising the identities of participants within the pragmatic-interactionist tradition.

The secondary data will be helpful in designing our future primary research and provides a baseline with which to compare our primary data collection results. As Fuchs (2017) notes, social media is a participatory culture and provides rich and diverse opportunities to develop secondary data analysis because of the binaried and non-binaried nature of data that is public and/or private. Researchers, however, should not overstate the creativity and activity of users on the web because of the potential for commodification and exploitation of users. We certainly kept this in mind and referred to Jenkins's (2009) three distinct levels of social media participation that can influence who owns and controls social media content. These levels are the production, selection and distribution of online content by internet prison sites. We ensured that we were attentive to the three levels in our observations of the range of forums that received high numbers of content and comment, and those that did not, while being conscious that where content was large and varied that this did not mean it was superior (see Fuchs 2017). It is important to note that gathering a large number of different prisoner content online is a form of participatory power in and of itself. As mentioned in our introduction, the prison online world is a form of mediatized social life that has produced a social practice, unique in world prison sociology. Although the data is more generally about mundane daily activities or opinions we hold the view that, nevertheless, the data conveys interesting insights into how Russian penality sits at the nexus of visibility and hiddenness.

The secondary data is presented in this paper in two different formats. The first format follows the more conventional qualitative coding practices of social science whereby we code the data according to common themes: everyday life in prison, families/access/absence, talking about difficulties and problems, relationships with staff, relationships with those living with you, getting support and help. The second format builds the discussion that de-institutionalisation increases the proximity of prisoners to the outside world and thus problematizes the territorial dimensions of incarceration to create re-territorialisation of prisoners. In both findings sections that follow, we select themes on the basis that these were the most common forum discussions. We add the cautionary note that, as we are in the very early stages of the online fieldwork, this is a small sample of some of our results and that we had no way of knowing the gender and age of our respondents, as these details are not provided so we were unable to cross-analyse the data. 


\section{The de-institutionalisation of prisons}

The web-site selected has six main forum sections and fourteen sub-sections contained within the main sections. The six forum subjects on www.jailRussia.org are:

1. The administration of the site;

2. cases in court and issues concerning trials;

3. implications of convictions: employment after prisons and travelling abroad;

4. release;

5. treatment and complaints; and

6. miscellaneous, including prison poems, songs stories and art.

Forums five and six are particularly revealing of the ways that imprisonment can be understood as occupying a de-institutionalised carceral space where prisoners ask each other - and not authorities - questions about the management of the prison. There are numerous and frequent disclosures from families struggling with contact, from prisoners worried about whether they will get health insurance and from Prison Visiting Committees. The descriptions are rich, random but detailed about "visits to bakery sections, living quarters and having conversations with young prisoners". One post outlines the ways that the prisoner and the prison can "work together to improve conditions":

After touring the facility, the institution held a meeting, which was attended by the head as well as his deputy for industry and educational work. The meeting discussed issues of cooperation, development work and the parents' committee, the administration of the institution and joint work plans for the coming months. We also discussed a number of urgent problems, in which the chief of the institution promised to deal with personally.

The forums outline the daily challenges of serving a sentence when guidelines, policies and rules are not issued. Performing the dual role of both a frequently asked questions and how to survive a Russian jail forum, the online forum is not a neutral instrument but one that reinforces a new spatial organization of how and where punishment is discussed. We see agency and structure are interlinked with an abundance of advice on "working with the regime" and constant feedback whereby prisoners are presented as not marginal but heavily implicated in successful prisons. This could be explained as due to a fear of surveillance. Yet, in the absence of access to advocates, families and legal support, this very process of engaging with the authorities may in turn have the effect of strengthening penal order, which magnifies a socio-political penal culture concerned more with preserving historical tropes than reforming them. For example, all forums we have read draw attention to and, indeed, promote penal history in order to help others better understand the quality of a carceral experience in Russia:

Here is where you are and here is how you got here.

Prison life is Gulag life. Let me tell you why.

These two quotes suggest that everyday discourse on punishment carries forward cultural motifs from the Gulag: "these are Russian prisons after all", "Gulag is Gulag always", "work with the collective and you'll survive", and "here is our history", with links to Gulag documentaries. At the same time, there are many dozens of postings on issues such as obtaining health insurance after imprisonment, how to make complaints, potential miscarriages of justice, practical advice on how to send parcels, what families can expect on arrival (advice given from prisoners), how to deal with beatings and prisoners advising on local human rights organizations. Some forums receive a couple of hundred views such as one on hunger strikes where in reply to a blogger writing about hunger strike, a forum participant stated:

You are not alone, get ready to hit the road and head to the colony and find out how being there can help in the colony and the prisoner. 
There are numerous discussions on how to ensure families can reach the remote penal colonies and these popular forums receive over ten thousand views. Conversely, there are regular posts on rights awareness. This suggests a nonbinaried form of agency and structure whereby prisoners are encouraged by family members to "fight and resist", yet at the same time to "engage". While it is relatively easy to name and shame any prison today through sending messages to the media through illicit devices, the online Russian prison world reveals that even if they are closed institutions, prisons are porous yet, nevertheless, are still part of the larger society and, as such, they cannot be forever walled off from technological changes. At the same time, in a country with a cultural attachment to incarceration, being online contests the notion of time spent inside institutions. This can be explained as coming about because, structurally, Russian prisons are sitting at a watershed moment in policy and legal terms, in that the online presence of prisoners raises new questions about how prison problems are verified and validated away from visible penal bureaucracies such as complaints procedures, reports from families and legal protocols. A further important finding is that prisoner agency is less about resistance and more about acquiring information about how to navigate and experience confinement. Being online enables prisoners, therefore, to be introduced to carceral life through information gathering, rather about being the space where prisoners resist.

Other ways in which Russian prisons are de-institutionalized are in the presence of lawyers online, who offer legal advice to prisoners through live web feeds. On many websites, pop-ups appear at the bottom of screens that show lawyers asking prisoners if they need advice on a "no win, no fee" basis. Some websites are so proficient with this facility that the user can immediately see the lawyer's name and photograph, which ultimately increases confidence for users. This is unusual in all penal cultures, which, as Calavitta and Jenness (2015) show in their work on prison bureaucracy in California, contain their hyper-legality within the prison walls. If law is the "unavoidable master" of the prison institutional context (Calavitta and Jenness 2015,105 ) in Russia, prisoners are de-institutionalizing the context. There is evidence of ways in which the online world is disrupting the fixed circuits of penal power as boundaried, contained and hidden:

In prison colony $X$, the punishment cell violated nutritional standards, that is, prisoners do not receive food put before them apart from bread and cereals. Prisoners are on hunger strike because the institution is not taking any action to resolve the situation.

This sense of dislodging prisons from their carceral context and onto a discursive space, conceptually at least, transforms penal structure beyond what is commonly referred to by human geographers as a "built environment" (see Moran 2015, 17). This suggests that the control flows of punishment are tenuously held within the prison walls. Emphasising the everyday in Russian prisons online exposes how in Russia, and perhaps everywhere, punishment cannot be contained. Moreover, since contact with families, lawyers and third sector groups is shifting from person-toperson to social media, then conventional modes of communication between inside and outside the prison walls are upended. The outcome then is both deinstitutionalisation and de-ritualization because communication has shifted - albeit not entirely - from person-to-person to a virtual reality.

In summary, the de-institutionalization of prisons has come about because of two factors. First, is the inevitability of the online social media boom where the internet is the conduit through which prisoners articulate the need for both everyday knowledge and penal knowledge. Second, is the historical carceral trajectory of penality in Russia where prisons are the collateral damage from a culture whereby political rights are not evenly distributed, the government is not accountable or responsive to its citizens, and economic opportunities for all Russians are greatly skewed. No longer concealed in form, function and ideology, prisons in the new internet age are revealing of contradictory and fluid knowledges of how prison is a 
cultural constraint and a constant that is both interrupted and engaged with. The inevitable outcome is a new socio-carceral spatial context that quite remarkably has made penality incredibly resilient despite the plethora of online web-sites and forums that shame specific prisons. We discuss this further in the section following. We now move on to our second finding that the de-institutionalization of prisons has increased both the proximity and distance of prisoners through re-territorialisation.

\section{The re-territorialisation of prisoners}

Mentioned previously was the rich history of prisoner memoirs in Russia that serve as cultural texts of the meanings and understandings of punishment in Russia. We have also shown that the internet as a place where prisoners talk is being used in ways to seek counsel, guidance, support, information, entertainment and intimacy with like others. This disrupts the conventional sociological ways of contextualising the prison along a thematic of exclusion and containment. An implicit new spatial geography can be discerned that calls into question the boundary between prisons and outside, and between agency and structure. In this section, we explore in more detail how prisoners are unmaking their absentism online. We do not offer direct quotes from prisoners but instead refer back to the broader forum subject areas discussed earlier and then make links to the wider human rights context. We adopt this approach because prisons are sites marked by acute disparities of power and structural constraint (Jewkes 2015) how do prisoners use the boundaries of the virtual world and reflect the experiences of those observed within it through the lens of human rights?

Prisoners in Russia access the internet illegally though smart phones used to broadcast a wide range of behaviours, experiences and thoughts. At the extreme end, there have been several broadcasts on YouTube from penal colonies of prisoners sewing their lips together, mass self-harm protests and more conventional roof top protests. According to the Russian Legal Information Agency, the volume of complaints about Russian prisons, particularly pre-trial remand prisons (SIZO) is so shocking that it led to the European Court of Human Rights (ECtHR) opting in 2012 to issue a pilot-decision (see ECtHR 2012) aimed at strengthening the protections guaranteed under Article 3 of the European Convention on Human Rights that prohibits torture and inhuman and degrading treatment (Council of Europe 2005). The prison system, the ECtHR argued, is so "structurally flawed" that it is broken due mainly to insufficient legal and administrative safeguards for prisoners and the volume of cases on pre-trial detention conditions. Russia has taken legislative steps to address issues of overcrowding and treatment of prisons in pre-trial prisons and there was the intention of building twenty-six new remand prisons by 2017. According to the leading human rights legal scholar Philip Leach, there has been little impact on how the penal system, or structure, is engaging in penal reform:

The Court (in more than 80 previous judgments in Russia), and the Council of Europe, have for more than ten years made it very clear that the deplorable state of many of Russia's over-crowded remand centres is utterly unacceptable. Although the problems, and their causes, are admittedly complex, given the excessive length of time, which has already passed since the Russian authorities have been on notice of this situation, the Ananyev action plan does not contain sufficient specific and concrete steps to ameliorate this situation. It is also deeply regrettable that it is envisaged that another four years will pass before certain measures are taken, during which time detainees will continue to live in inhuman conditions. (Leach, cited in Burke 2013)

There are two key points to bear in mind when considering the international case law on violations against the Russian prison service. First is that, although prison litigation has led to the visible mobilisation of rights awareness, in practice it has produced a culture of legal and, crucially, administrative uncertainty because of the "unwieldy logics of incarceration and rights that the prisoner grievance system straddles" (Calavitta and Jenness 2015, 115). While more obviously the overarching need of 
any prison is to affirm carceral control while ensuring that prisoners have the right to challenge that control, less obviously, are the ways that process, procedure and bureaucracy often lead to emotional detachment "dislodged from the mind of the individual knower" (Silbey, quoted in Calavitta and Jenness 2015, 128). For a penal jurisdiction like Russia, the degree of scale of this tension between control and rights is acutely felt, and complicated by a society that exercises an administrative, bureaucratic and authoritarian culture of control. Strict rules, paperwork and administrative logics have de-centred prisoners from seeking to raise awareness about the subjective experiences of incarceration because the rules offer little help. While a lot depends on the regions and the individual administration, prisoners in Russia are invisible again because of an insulated wall of bureaucracy that serves to protect rules and laws for the benefit of prisons. The second point is that the involvement of civil society is key in improving matters in prison. According to Leach (cited in Burke 2013), "it is important that the [Russian] Government's response [to ECtHR prison rulings] should be open to thorough public scrutiny - the authorities should be actively engaging with civil society over the adequacy of their proposals, and responding to any concerns expressed by amending their plans". It is into this dual context of rhetorical, cultural deference to rules and laws that form under a carceral logic of control through bureaucracy, and an escalating weakening of civil society, that has enabled a socio-carceral context of prisoner-internet activity to surface.

As mentioned earlier, there are documented acts of prisoner resistance that are shocking and it is worth considering them briefly here as they are also politically and culturally symbolic of how prisoner agency is neither uni-directional or fixed. In many of the protests that appear on YouTube, prisoners recall - with melancholic nostalgia - the cultural forms of Soviet penal confinement, where the penal was embedded into everyday life, where the trope of confinement is imagined in popular culture, through song and television shows. We recognise that the online world creates spatial mobility and a form of self-expression that parallels well with how most people interact with social media, insofar as it allows them to express diverse insights and emote in fluid, unregulated and unstructured ways. Yet, we argue also that when Russian prisoners refer to their rights, they point to penal legacies and the inertia of authorities while articulating a continuous history of state/penal bureaucracy. For Russian prisoners, this clustering of insights into how the outside world of rights entitlements interacts with the complex and hidden world of punishment and the placing of experiences in historical carceral motifs produces a host of new spatial metaphors of longing and belonging and moving from the body to embodiment. This is most marked in the culture of prison tattooing, where a double consciousness develops through the identification of rights violations with Soviet penality and with a more modern, more Westernised penal actor who is an autonomous self-expressing agent.

The online prison world matters because, while Russia remains a remote research site culturally and geographically, prisons have become proximate and porous. These everyday discussions certainly remind us that punishment, everywhere, exists to internally impose ideas of power, control and risk. The content of online prisoner chat also suggests that when bodies captured in prison are placed onto online spaces, then punishment and prisoners themselves become constituted, imagined and articulated differently. This creates a somewhat paradoxical status of bodies captured and bodies free. The re-territorialisation of prisoners suggests, therefore, a fluid prisoner identity in constant state of re-construction; the self-constructed as reliant on like others found on chat rooms; the prisoner no longer a passive, hidden subject of state punishment. Agency, on the one hand, is a sensibility organised around distributing feelings and experiences using unconventional means. On the other hand, it has the effect whereby penality is normalised.

Online prisoner narratives call to mind Soja's work on thirdspace, where he argues that online media produce identities reconstituted in a very social way that provide 
coherence and stability (Soja 1998). This is not to suggest a false harmony amongst prisoners online, but it does suggest that prisoners agency in Russia is the outcome of a process of de-institutionalisation of prisons thathas enabled a reterritorializing of penal space through self-expression that is online and, in some sense, free from bureaucratic inertia and state/penal power. In a deeply constraining environment like a Russian prison, this is significant because it marks a new stage in the evolution of Russian prisoners' troubled and exceptional penal historical development. This would suggest that Russian incarceration's century long cultural trope of carceral collectivism, borne from the Soviet penal architecture of mass accommodation in fixed institutional sites, is evolving yet again towards something new and unique in world penal systems (see Piacentini and Slade 2015). Through the techno-cultural mediation form of the internet, prisoners are collectivising - once again - around their feelings and their need to acquire penal knowledge. The type of temporality that is present may be virtual, but a core ingredient to the online world is a commitment to sharing the experience of punishment. The question then is less about whether this is a good or bad thing in itself but what this blending of agency and structure in Russian prisons reveals about cultures of punishment. In the section that follows, we revisit our conceptual framework mentioned earlier on in the paper around how the process of de-institutionalisation and re-territorialisation has led to prisoners unmaking their absence.

\section{Prison as a repository for the absent}

In considering that Russian prisoners are unmaking their absence online, there are several points to note. More generally, when people think of thirdspace, they think of a space where they are not. So when prisoners communicate online, do they perceive of themselves as spatially mobile or visible? Relatedly, where two prisoners or prisoners' families are communicating at their individual computer terminals or through smart phones, where are they in reality when they interact? An analytical framing of prisoners as absent can improve our understanding of what is happening because it shifts how the prison is represented and imagined away from its physicality, and unsettles the distinction between the prison and the outside world and between visibility and absence. Earlier in our paper, we referred to Rubin's work on how structure contributes to prisoner behaviour and is co-productive of it (Rubin 2016). Our findings suggest something similarly nuanced is happening in Russian prisons around the use of the internet, which may offer the only material prisoners have to hand to express their agency. Key to our understanding of the relationship between agency and structure is that most prisoners engage online to obtain a modicum of understanding of penal rules, policies and practices and to access the bureaucratic and administrative procedures that are not available (or maybe even are denied them). This sense of living in an institutional environment that remains militaristic, bureaucratic and concentrated around authoritarian carcerality is historically embedded and culturally contingent and, crucially, it connects to the everyday and routine disenfranchisement of citizens in Russia more broadly. This is described as "bi-directionality (prisoners simultaneously use and challenge the regime)" (Rubin 2016). Thus, on the one hand, there is the prisoner who appears to not count, but there is also the prisoner who engages and because - we contend - of the wider social context where Russian citizens are living with resilient cultural traditions of authoritarian power. Indeed wider disenfranchisement of citizens suggests the need to broaden out a conceptual framework of absence to wider Russian society.

\section{Conclusion}

Russian imprisonment is now a site for global public intimacy due to the widespread use of illicit communications in prisons. In developing a new analytical framework of "prisoners as absent" who are present and who are not present our aim in this paper has been to locate new and dynamic forms of prisoner online discourse within a 
complex penal culture that has a particularly troubled past. Our main finding is that prisons are de-institutionalised from their built environment, creating an open penal border and limitless encounters, and that prisoners are hence re-territorialising themselves into bodies no longer hidden. Communication is forceful but less confined, open, but also risks a strong authoritarian response. This is a unique finding in the study of world penal systems because never before in the history of incarceration have we seen such openness to blog, talk and discuss feelings about confinement in a contemporary penal system still rarely examined. Prisoners' willingness to talk about their lives, their troubles and conditions should be seen in this broader, exceptional context. We also found that the internet has become a cultural tool for revealing particular constructions of penality that shape, mirror and parade Russian imprisonment's cultural and historical identity rather than solely signifying resistance to it.

A few questions appear immediately pressing from this paper. First, is that we are only now starting to understand the relationship between digital technology and imprisonment (research so far focusses on the use of technology for offender rehabilitation, see Knight 2016) and this paper contributes to that field. Second is that the ways in which prisoners subjectively understand confinement as a place of punishment, stigma and isolation, or as a place of rights empowerment, raises questions about how - and, importantly, where - prisoners discuss their incarceration and the connects or disconnects to state and penal power that the internet provides knowledge of, if not access to. Third is how the Russian prison service is responding to the increasing use of illicit devices. What we know is that the Russian prison service has passed legislation that bans mobile phone use and prosecutes families. There are mobile phone signal blockers and drones used to pick up any phone drops. Related to this is how the prison service is engaging with the content of the web-sites particularly those that have pop-up lawyers and forums focusing allegations of rights violations. We are aware that the prison service may monitor web-sites although it is very difficult to ascertain if prisoners are being targeted as a result. To establish if that is the case would require engagement with civil society groups but many of these are banned. Complicating this further is that the litigation that is making its way through the Strasbourg courts comes from conventional forms of pursuing rights violations (we are not aware of any cases that have come about because of online prisoner activity).

Finally, one of the most significant observations from this study has been how in unmaking their absent-ism, prisoners are producing and re-producing new spaces of mobilising self-expression in a country whose transition to democracy has taken several steps backwards. For Russian prisoners, the internet is not a passive surface. It may be under-ground but it is representational of how prisoner societies cohere around a historically troubled status. Prisoner online engagement is risky but being online allows prisoners to have influence in the production of their new spatial territory. In other words, it allows them to be potentially influential in their own penal story because social media makes carceral experiences visible. Moreover, online prisoner engagement not only disrupts the more visible bureaucracies of rights mobilisation (penal reform, legal grievance systems and person-to-person advocacy), but has produced on a new penal imaginary - a carceral motif for the twenty first century - in the form of a virtual world.

\section{References}

Baberowski, J., et al., eds., 2015. Kritika: Explorations in Russian and Eurasian History [online], 16 (3, Special issue: The Soviet Gulag: New Research and New Interpretations). Available from: https://muse.jhu.edu/issue/32389 [Accessed 24 January 2018].

Barnes, S., 2011. Death and Redemption: The Gulag and the Shaping of Soviet Society. Princeton University Press. 
Bosworth, M., 1999. Engendering Resistance: Agency and Power in Women's Prisons. London: Routledge.

Bosworth, M., 2016. Border Criminologies: How migration is changing criminal justice. In: M. Bosworth, C. Hoyle and L. Zedner, eds., Changing Contours of Criminal J ustice. Oxford University Press.

Bowring, B., 2013. Law, Rights and Ideology in Russia: Landmarks in the destiny of a great power. London: Routledge.

Boyd, D., and Crawford, K., 2012. Critical questions for big data. Information, Communication \& Society [online], 15 (5). Available from: http://www.tandfonline.com/doi/abs/10.1080/1369118X.2012.678878 [Accessed 24 January 2018], pp. 662-679.

Burke, I., 2013. Russia scrambles to improve detainee rights record under ECHR guidance. Rapsi. Russian Legal Information Agency [online], 9 January. Available from:

http://www.rapsinews.com/judicial_analyst/20130109/265853623.html [Accessed 24 January 2018].

Calavitta, K., and Jenness, V., 2015. Appealing to Justice: Prisoner Grievances, Rights and Carceral Logic. Berkeley, CA: University of California Press.

Callinicos, A., 2009. Making History: Agency, Structure, and Change in Social Theory: Historical Materialism. Chicago, IL / New York: Haymarket books.

Carrington, K., 2015. Feminism and Global J ustice. London: Routledge.

Carrington, K., et al., eds., 2012. Crime, Justice and Social Democracy: International Perspectives. Basingstoke: Palgrave Macmillan.

Council of Europe, 1950. European Convention on Human Rights, as amended by Protocols Nos. 11 and 11, supplemented by Protocols Nos. 1, 4, 6,7, 12 and 13 [online]. Rome, 4 November. Available from: http://www.echr.coe.int/Documents/Convention_ENG.pdf [Accessed 24 January 2018].

Council of Europe, 2004. Protocol No. 14 to the Convention for the Protection of Human Rights and Fundamental Freedoms, amending the control system of the Convention. CETS No. 194 [online]. Strasbourg, 13 May. Available from: https://www.coe.int/en/web/conventions/full-list/-/conventions/treaty/194 [Accessed 1 February 2018].

Coyle, A., 2009. A Human Rights Approach to Prison Management. Handbook for Prison Staff. London: International Centre for Prison Studies.

Crawford, A., and Hutchinson, S., 2016. Mapping the Contours of 'Everyday Security': Time, Space and Emotion. The British J ournal of Criminology [online], 56 (6), pp. 1184-1202. Available from: https://doi.org/10.1093/bjc/azv121 [Accessed 24 January 2018].

Deuze, M., 2011. Media Life. Media, Culture and Society, 33 (1), pp. 137-148.

Drake, D., Earle, R., and Sloan, J., 2015. The Palgrave Handbook of Prison Ethnography. Basingstoke: Palgrave Macmillan.

Edkins, J., 2011. Missing: Persons and Politics. Ithaca, NY: Cornell University Press.

European Court of Human Rights, 2012. Russia required to take urgent action regarding inhuman and degrading conditions of pre-trial detention [online]. Press release issued by the Registrar of the Court. 10 January. Available from: https: //hudoc.echr.coe.int/app/conversion/pdf?library=ECHR\&id=0033800862- 
4354469\&filename $=$ Chamber\% 20judgment $\%$ 20Ananyev $\% 20$ and $\% 200$ thers $\%$ 20v.\%20Russia\%2010.01.12.pdf [Accessed 2 February 2018].

Federal Penitentiary Service of Russia, 2013. Director Gennady Kornienko visit Norway and Finland [online]. Press release, 11 J une. Available from: http://www.fsin.su/eng/news/index.php?ELEMENT_ID=96694 [Accessed 23 January 2018].

Fletcher, R., 2006. The impact of culture on website content, design and strtcure. An International and multicultural perspective. Journal of Communication Management, 10 (3), pp. 259-273.

Fuchs, C., 2017. Social Media: A Critical Introduction. $2^{\text {nd }}$ Edition. Thousand Oaks, CA: Sage.

Gibson, M., 2016. YouTube and Bereavement Vlogging: Emotional exchange between strangers. Journal of Sociology [online], 52 (4), 631-645. Available from:

http://journals. sagepub.com/doi/abs/10.1177/1440783315573613?journalCo de=josb [Accessed 24 J anuary 2018].

Ginzburg, E., 1967. Journey into the Whirlwind. New York: Harcourt, Brace \& World.

Gordon, A., 2011. Some Thoughts in Haunting and Futurity. Borderland, 10 (2), pp 1-21.

Grossman, V., 1965/2009. Everything Flows. Trans.: Robert Chandler, Elizabeth Chandler, and Anna Aslanyan. New York: NYRB Books.

Hannah-Moffat, K., 2001. Punishment in disguise: penal governance and federal imprisonment of women in Canada. Toronto University Press.

Hannah-Moffat, K., 2014. Moving targets: Reputational risk, rights and accountability in punishment [online]. Slides from the $8^{\text {th }}$ Annual Lecture of the Scottish Centre for Crime and J ustice Research. The University of Glasgow, 19 May. Available from:

http://www.sccjr.ac.uk/publications/moving-targets-reputational-risk-rightsand-accountability-in-punishment [Accessed 1 February 2018].

Hines, C., 2015. Ethnography for the Internet: Embedded, Embodied, Everyday. London: Bloomsbury.

Hjorth, L. and Lim, S.S., 2012. Mobile intimacy in an age of affective mobile media. Feminist Media Studies [online], 12 (4), 477-484. Available from: https://doi.org/10.1080/14680777.2012.741860 [Accessed 24 January 2018]

Holquist, P., 2003. State Violence as Technique: The Logic of Violence in Soviet Totalitarianism. In: A. Weiner, ed., Landscaping the Human Garden: Twentieth Century Population Management in a Comparative Framework. Redwood City, CA: Stanford University Press.

Jenkins, H., 2009. Confronting the Challenges of Participatory Culture. Cambridge, MA: The MIT Press, coll. MacArthur Foundation Reports on Digital Media and Learning.

J ewkes, Y., 2015. Fear Suffused Hell Holes: The Architecture of Extreme Punishment. In: K. Reiter and A. Koelig, eds., Extreme Punishment Comparative Studies in Detention, Incarceration and Solitary Confinement. London: Palgrave Macmillan.

Khlevniuk, O., 2015. The Gulag and the Non-Gulag as One Interrelated Whole. Trans.: Simon Belokowsky. Kritika: Explorations in Russian and Eurasian History [online], 16 (3, Special Issue: The Soviet Gulag: New Research and 
New Interpretations), 479-498. Available from:

https://muse.jhu.edu/article/591088 [Accessed 24 January 2018].

Knight, V., 2016. Remote Control: Television in Prison. London: Palgrave Macmillan.

Kozinets, R., 2015. Netnography: Doing Ethnographic Research Online. Thousand Oaks, CA: Sage.

McAuley, M., 2016. Human Rights in Russia: Citizens and the State from Perestroika to Putin. London: I.B. Tauris.

Moran, D., and Disney, T., 2017. 'It's a horrible, horrible feeling': ghosting and the layered geographies of absent-presence in the prison visiting room. Social \& Cultural Geography [online]. First published 1 September. Available from: https:// doi.org/10.1080/14649365.2017.1373303 [Accessed 24 January 2018].

Moran, D., 2015. Carceral Geography: Spaces and Practices of Incarceration. London: Routledge.

Pallot, J., 2013. Penitentiary Systems in the Era of Internet Services in Russia. Laboratorium, Russian Review of Social Research [online], 3. Available from: http://www. soclabo.org/index.php/laboratorium/article/view/356/946 [Accessed 23 January 2018].

Paperno, I., 2009. Stories of the Soviet Experience: Memoirs, Diaries, Dreams. Ithaca, NY: Cornell University Press.

Parr, H., and Fyfe, N., 2013. Missing geographies. Progress in Human Geography [online], pp. 1-24. Available from: http://eprints.gla.ac.uk/73806/1/73806.pdf [Accessed 24 January 2018].

Pauwels, L., 2011. Researching Websites as Social and Cultural Expressions: Methodological Predicaments and a Multimodal Model for Analysis. In: E. Margolis and L. Pauwels, eds. The Sage Handbook of Virtual Research Methods. Thousand Oaks, CA: Sage.

Payne, M., 1995. Understanding 'going missing': Issues for social work and social services. British J ournal of Social Work, 25 (3), 333-348.

Piacentini, L., 2004. Surviving Russian Prisons: Punishment, Economy and Politics in Transition. Cullompton: Willan.

Piacentini, L., and Katz, E., 2017. Carceral framing of human rights in Russian prisons. Punishment and Society, 19 (2), 221-239.

Piacentini, L., and Slade, G., 2015. Architecture and Attachment: Carceral collectivism and the problem of prison reform in Russia and Georgia. Theoretical Criminology [online], 19 (2), 179-197. Available from: http://dx. doi.org/10.1177/1362480615571791 [Accessed 23 January 2018].

Pittendrigh, N., 2015. Making Visible Invisible Suffering: Non-deliberative Agency and the Bodily Rhetoric of Tamms Supermax Prisoners. In: K. Reiter and A. Koelig, eds., Extreme Punishment Comparative Studies in Detention, Incarceration and Solitary Confinement. London: Palgrave Macmillan.

Pomerantsev, P., 2014. Nothing is True and Everything is Possible: The Surreal Heart of the New Russia. New York: PublicAffairs.

Ratushinskaya, I., 1988. Grey Is the Colour of Hope. Trans.: Alyona Kojevnikov. London: Hodder and Stoughton.

Rhodes, L., 2004. Total Confinement: Madness and Reason in the Maximum Security Prison. Berkeley, CA: University of California Press. 
Rosen, C., 2012. Electronic Intimacy in the Age of Connection. The Wilson Quarterly [online], spring, pp. 48-51. Available from:

https://www. wilsonquarterly.com/quarterly/spring-2012-the-age-ofconnection/electronic-intimacy/ [Accessed 24 J anuary 2018].

Rubin, A., 2016. Resistance as Agency? Incorporating Structural Determinants of Prisoner Behaviour. The British J ournal of Criminology, 53 (3), 644-663.

Soja, E.W., 1998. Thirdspace: Journeys to Los Angeles and Other Real and Imagined Places. Cambridge, MA: Blackwell.

Solzhenitsyn, A., 1973. The Gulag Archipelago. Trans.: Thomas P. Whitney. London: Collins and Harvill.

Suler, J., 2004. The online disinhibition effect. Cyberpsychology and Behavior, 7 (3), 321-326.

The Moscow Times, 2015. Enterprising Accomplices Launch Drone Carrying Cell Phones into Russian prison. The Moscow Times [online], 20 July. Available from: https://themoscowtimes.com/news/enterprising-accomplices-launchdrone-carrying-cell-phones-into-russian-prison-48387 [Accessed 23 January 2018].

van Riel, M., 2015. More Than a Decade after Kalashnikov, Russian Prisons Still Abysmal. Open Society Foundations [online], 24 June. Available from: https://www. opensocietyfoundations.org/voices/more-decade-afterkalashnikov-russian-prisons-still-abysmal [Accessed 23 January 2018]. 